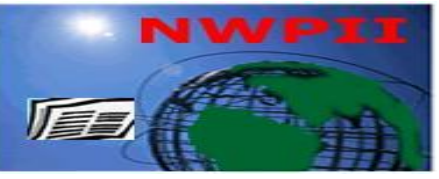

American Journal of Biomedical Sciences

ISSN: 1937-9080

nwpii.com/ajbms

\title{
Induction of Chronic Pneumonia in Normal Mice by Klebsiella pneumoniae
}

\author{
Sonica Sharma ${ }^{1}$, Sanjay Chhibber ${ }^{1}$, Harsh Mohan $^{2}$, Saroj Sharma ${ }^{1 *}$ \\ ${ }^{1}$ Department of Microbiology, BAMS Block, Panjab University, Chandigarh, India \\ ${ }^{2}$ Department of Pathology, Government Medical College, Sector-32, Chandigarh, India \\ *Corresponding author: \\ Saroj Sharma, M.D. \\ Department of Microbiology \\ BAMS Block \\ Panjab University \\ Chandigarh, India \\ Tel: +91 9968245350 \\ Email: sonica.sharma@sify.com
}

Received: 4 May 2011; | Revised: 16 November 2011; $\mid$ Accepted: 8 December 2011

\begin{abstract}
Experimental chronic pneumonia was established in normal BALB/c mice employing a virulent encapsulated strain of Klebsiella pneumoniae B5055. A single exposure to the bacterial pathogen resulted in acute pneumonia that resolved within a week. To achieve the chronic state of lung infection, repeated infection was given via intranasal route. Mice were inoculated with $50 \mathrm{ul}$ of $10^{4} \mathrm{CFU} / \mathrm{ml}$ each on day 0,7 and 14. There were two peaks observed in the assessment of the lung bacterial load and pro inflammatory cytokine generation following the first and the third infection, respectively. On day 18 of infection, histopathological examination revealed extensive chronic inflammatory changes in the lungs of infected mice which coincided with high lung bacterial load. Tissue damage was also assessed through analysis of malondialdehyde (MDA), lactate dehydrogenase (LDH), and nitric oxide generation in the lung homogenates of the infected mice.
\end{abstract}

Keywords: Chronic pneumonia, Klebsiella pneumoniae, mice, cytokines.

\section{Introduction}

Lower respiratory tract infections have always remained a cause of concern for medical fraternity throughout the world. Gram negative bacteria are the predominant causative agents of these infections. Amongst these, Klebsiella pneumoniae is commonly associated with both community acquired and nosocomial pneumonia resulting in severe lung infection with high mortality rates or establishment of chronic pneumonia in untreated cases $[1,2]$. At times, even the immunocompetent elderly as well as the healthy non-elderly adults are at a risk of developing pneumonia [3].

Well characterized animal models, that mimic clinical infections in man, are very useful in providing precise insight into the pathogenesis of infectious diseases as well as in evaluation of 
antibiotic treatment schedules in human infections under similar conditions of intensity and duration of infection. There are several animal models described in literature in relation to acute pneumonia, but very few studies are available where chronic pulmonary infection has been established in experimental animals. Initially, Berendt et al. [4] and Domenico et al. [5] developed chronic bronchopneumonia in rats with $K$. pneumoniae. However, the use of mice in experimental studies has increased over the last two decades due to economic factors, easy availability and the genetic similarity between mice and humans [6]. Iizawa et al. [7] were the first to establish chronic pulmonary infection in mice by aerosol inoculation of $K$. pneumoniae. These workers also investigated the susceptibility of different strains of mice to experimental infection. But high mortality in experimental animals observed in the earlier or later phase was the main limitation in these studies.

In the present study, an effort was made to establish chronic pneumonia in normal BALB/c mice with $K$. pneumoniae. The mice were infected with the bacteria three times at weekly intervals via intranasal route and the host response in terms of inflammatory changes was studied.

\section{Materials and Methods}

\subsection{Bacterial strain}

Klebsiella pneumoniae B5055 strain (serotype O1:K2) obtained from Dr. Mathia Trautman, Department of Medical Microbiology and Hygiene, University Of Ulm, Germany, was used in the study. Bacterial strain maintained on nutrient agar slants, was grown in static culture in

nutrient broth at $37^{\circ} \mathrm{C}$ for $18 \mathrm{~h}$, harvested by centrifugation at $2400 \mathrm{~g}$ for $15 \mathrm{~min}$. Following three consecutive washings, the organism was suspended in phosphate buffered saline (PBS, $0.2 \mathrm{M}, \mathrm{pH} 7.2)$ to the desired concentration.

\subsection{Maintenance of organism}

The bacterial strain was maintained at $-70^{\circ} \mathrm{C}$ in tryptic soy broth (Hi media, Mumbai) containing $20 \%$ glycerol. For each experiment, bacteria were revived from the stock, inoculated in tryptic soy broth and finally streaked on tryptic soy agar.

\subsection{Animals}

Specific pathogen free BALB/c mice of either sex, 4-6 weeks old, weighing 20-25g procured from the Central Animal House, Panjab University, Chandigarh, were used in the study. Animals were kept in clear polypropylene cages and fed on standard antibiotic free synthetic feed (JBD Agencies Pvt. Ltd., India) and water ad libitum. The study protocol was approved by the institutional ethical committee of Panjab University for animal experimentation.

\subsection{Induction of chronic pneumonia by intranasal route}

To establish chronic pneumonia by $K$. pneumoniae $\mathrm{B} 5055$, mice were given three intranasal doses of $10^{4} \mathrm{CFU} / \mathrm{ml}$ each. Following the first instillation of $50 \mu \mathrm{l}$ inoculum on day zero, two repeated doses were administered subsequently, on day 7 and day 14. Mice were sacrificed at different time intervals post infection. Lungs were removed aseptically and were examined for bacterial counts and histopathology.

\subsection{Bronchoalveolar lavage (BAL)}

Bronchoalveolar lavage was performed to obtain BAL cells and fluid as described by Laichalk et al. [8]. Following exposure of trachea, mice were intubated with a polyethylene catheter (1.0mm OD) and BAL was performed with $1 \mathrm{ml}$ sterile PBS. 0.5-0.6 ml lavage was retrieved from each mouse, centrifuged at 10,000 rpm for $5 \mathrm{~min}$. Supernates were collected and stored at $-80^{\circ} \mathrm{C}$ for cytokine analysis and pellet was stained with Wrights' Giemsa solution to determine PMN count in BAL fluid.

\subsection{Harvesting of Lungs for Biochemical and Cytokine analysis}

On different days, mice were sacrificed and pulmonary vasculature was perfused with $1 \mathrm{ml}$ PBS containing $5 \mathrm{mM}$ EDTA. After removal, whole lungs were homogenized in $1 \mathrm{ml}$ PBS, homogenates incubated on ice for $30 \mathrm{~min}$ and then centrifuged at $1500 \mathrm{~g}(10 \mathrm{~min})$. Supernates were passed through $0.45 \mu$ filter and stored at $-80^{\circ} \mathrm{C}$. 


\subsection{Biochemical Estimations}

Nitric oxide level in BALF of infected mice was studied through nitrite estimation following the colorimetric method of Griess as described by Tsai et al. [9]. Malondialdehyde (MDA) was estimated in infected lungs according to the modified method of Wills et al. [10]. Lactate dehydrogenase (LDH) enzyme activity was measured in the lung tissue homogenates by a photometric assay of Vassault et al. [11].

\subsection{Cytokine Estimations}

The quantification of TNF- $\alpha$ in BALF was done by using standard ELISA set (Pharmingen, B.D., U.S.A.). IL-1 $\beta$ and IL-10 were quantified using standard ELISA Kits (Calbiochem, U.S.A.) as per manufacturer's instructions.

\subsection{Statistical analysis}

Each experiment was done three times. All the results were analyzed by applying Students ' $t$ ' test and by calculating ' $p$ ' values. Data is expressed as mean \pm standard error.

\section{Results}

Chronic pneumonia was established in the $\mathrm{BALB} / \mathrm{c}$ mice with $K$. pneumoniae B5055. Animals were given three intranasal challenges, each consisting of $50 \mu \mathrm{l}$ of $10^{4} \mathrm{CFU} / \mathrm{ml}$ inoculum. Infection was given on day 0,7 and 14. There was a high bacterial load on the third day of infection followed by a decline in lung bacterial load till day 7 and again a steady increase in the lung bacterial load after second and third infection. Elevated bacterial counts were observed till $20^{\text {th }}$ post infection day and declined gradually thereafter (Fig. 1).

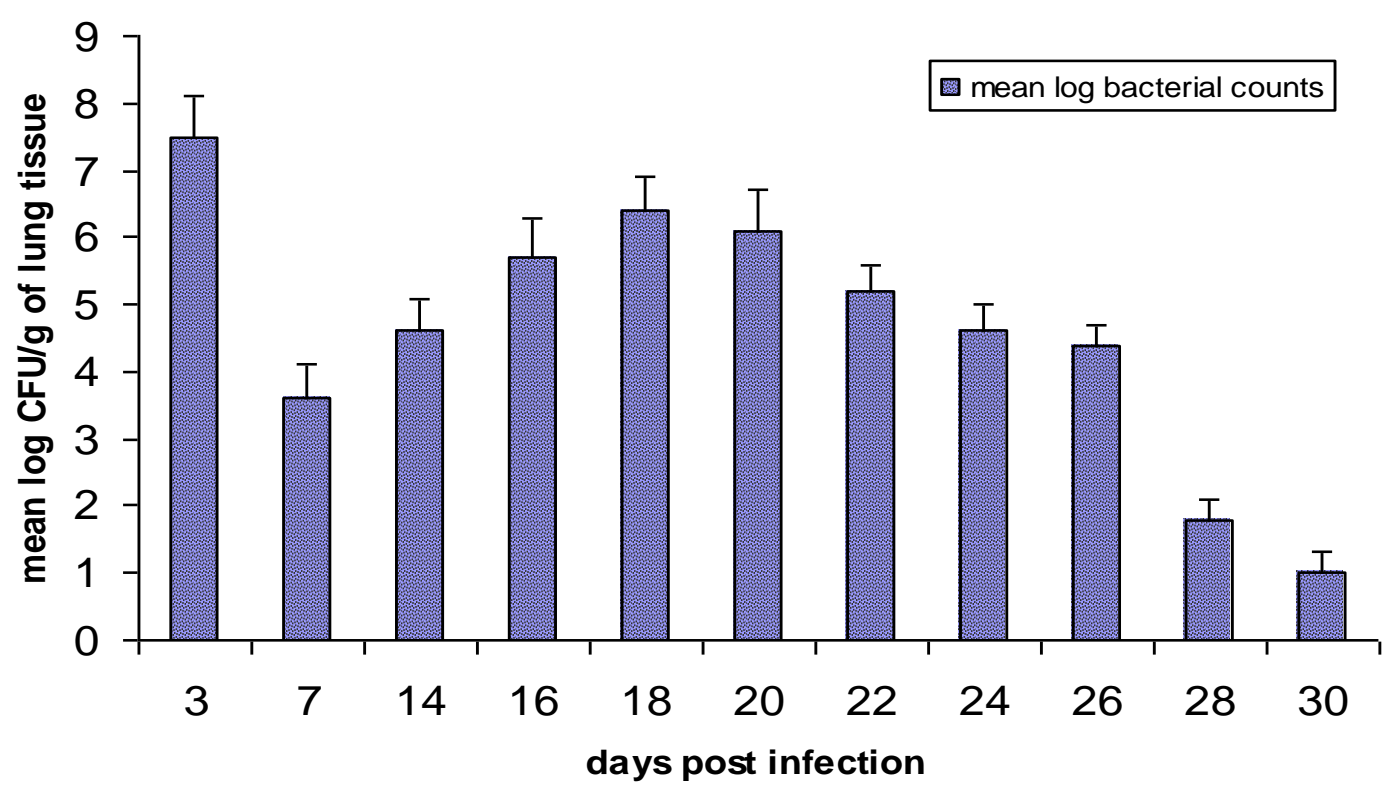

Figure 1: Bacterial counts in the lungs of mice infected with $K$. pneumoniae B5055 induced chronic pneumonia. Error bars indicate the standard errors of mean. 4 mice were sacrificed at each time point. The experiment was done in triplicate.

The corresponding lung pathology revealed severe acute inflammatory changes in the lungs of infected mice on the third day of infection (Fig. 2 b). After the second infection $\left(14^{\text {th }}\right.$ post infection day), mild chronic inflammatory changes in the alveoli were observed. However, extensive chronic inflammation characterized by lymphocytes, plasma cells and macrophage 
infiltrate, was observed after the animals were given the third infection. On $18^{\text {th }}$ post infection day, chronic abscess formation was noted with fibroblastic proliferation around the bronchioles along with alveolar destruction at certain places (Fig. 2 c, d). From $24^{\text {th }}$ day onwards, moderate peribronchiolar and alveolar inflammation could be seen with partial resolution of chronic infection.

(a)

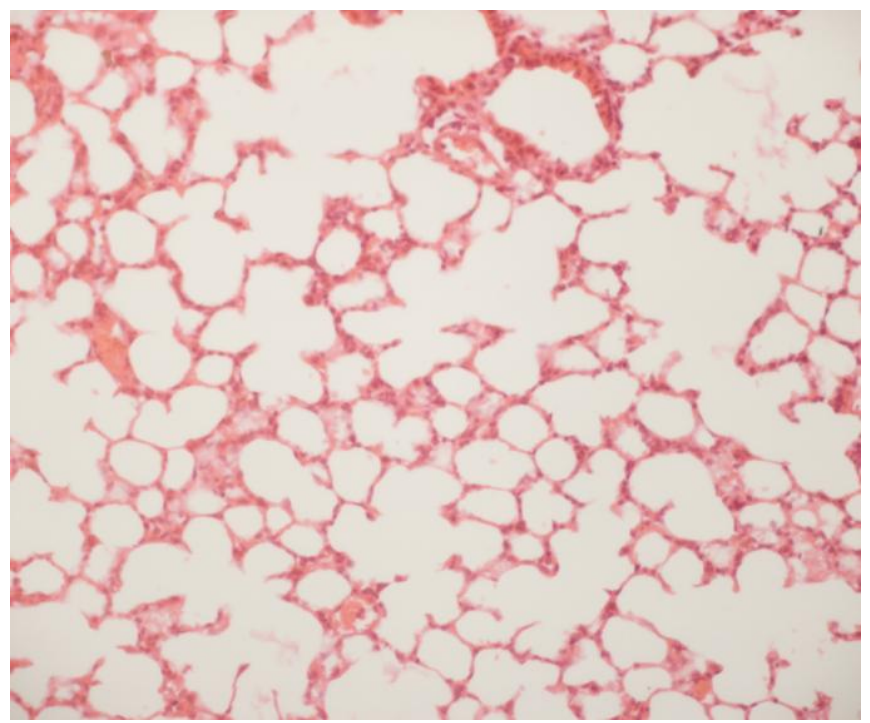

(b)

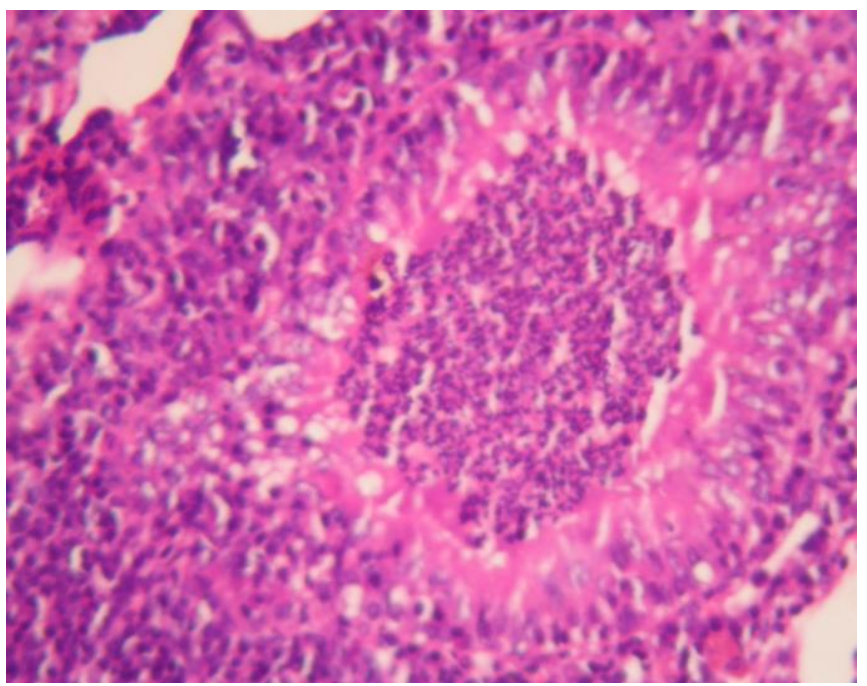

(c)

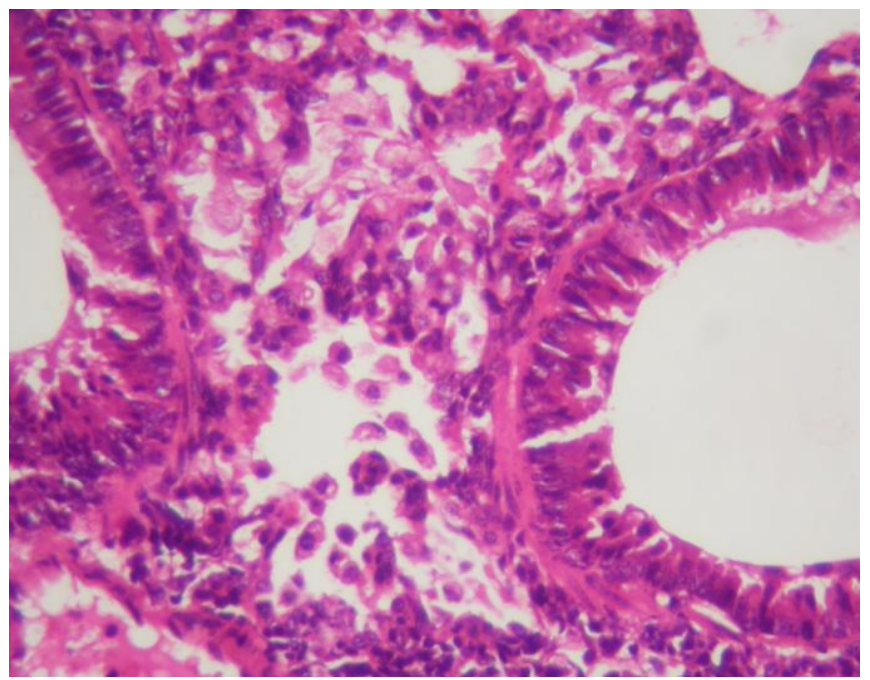

(d)

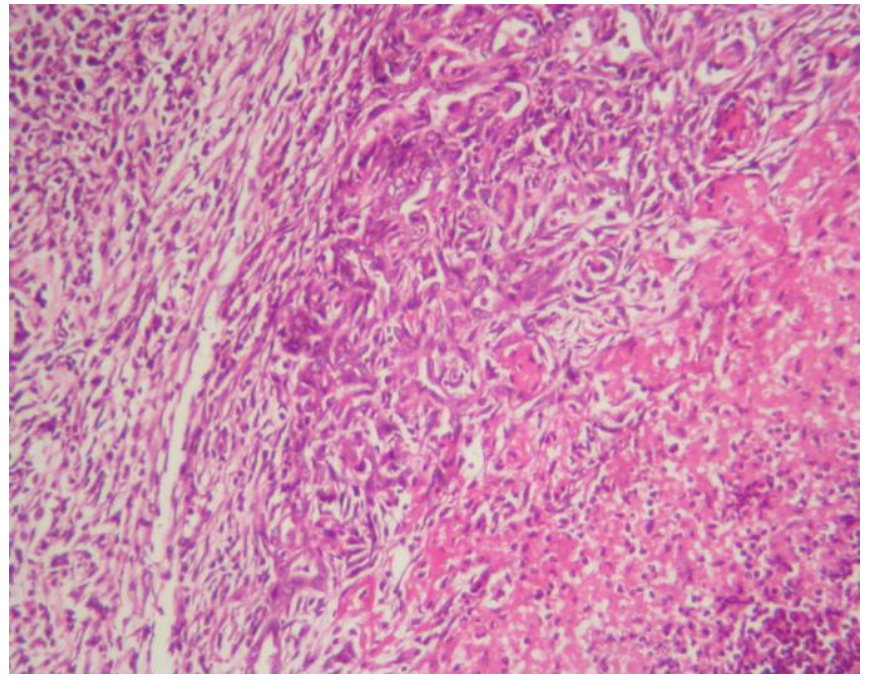

Figure 2: Representative photomicrographs of hematoxylin and eosin stained sections of lungs from mice with chronic pneumonia induced with $K$. pneumoniae. (H\&E x 200) (a) Normal uninfected lung. (b) Day 3. Bronchiole contains mucopus and destroyed wall; surrounding alveoli show loss of aeration, infiltration by neutrophils and intraluminal oedema fluid. (c) Day 14. The alveoli show presence of luminal infiltrate of macrophages and a few lymphocytes admixed with plasma cells. (d) Day 18. The field shows an abcess cavity containing necrotic slough and neutrophilic exudate. The wall of the cavity is composed of young fibrous tissue and infiltration by lymphomononuclear cells. 
Table 1: Levels of Nitrite, MDA and LDH in the lung homogenates of mice with chronic pneumonia induced by $K$. pneumoniae B5055. Data is expressed as mean \pm standard error. * denotes that $p>0.05$ when compared to the uninfected controls; $p<0.05$ for all other values when compared to levels of the control group.

\begin{tabular}{|c|c|c|c|}
\hline $\begin{array}{c}\text { Days post first } \\
\text { infection }\end{array}$ & $\begin{array}{c}\text { Nitrite production } \\
(\mathbf{m M} / \mathbf{m l})\end{array}$ & $\begin{array}{c}\text { LDH production(U/mg } \\
\text { protein) }\end{array}$ & $\begin{array}{c}\text { MDA production(ng/mg } \\
\text { protein) }\end{array}$ \\
\hline Uninfected controls & $12 \pm 4$ & $0.7 \pm 0.3$ & $0.8 \pm 0.3$ \\
\hline 3 & $112 \pm 7$ & $8.1 \pm 0.5$ & $6.8 \pm 0.4$ \\
\hline 7 & $50 \pm 5$ & $4.3 \pm 0.3$ & $5.0 \pm 0.4$ \\
\hline 14 & $65 \pm 5$ & $5.5 \pm 0.4$ & $5.6 \pm 0.4$ \\
\hline 16 & $85 \pm 7$ & $7.1 \pm 0.4$ & $6.7 \pm 0.5$ \\
\hline 18 & $105 \pm 8$ & $8.2 \pm 0.8$ & $6.9 \pm 0.6$ \\
\hline 20 & $95 \pm 6$ & $8.0 \pm 0.7$ & $6.8 \pm 0.7$ \\
\hline 22 & $75 \pm 5$ & $7.5 \pm 0.5$ & $6.6 \pm 0.6$ \\
\hline 24 & $50 \pm 5$ & $7.3 \pm 0.6$ & $6.2 \pm 0.5$ \\
\hline 26 & $35 \pm 3$ & $6.2 \pm 0.3$ & $5.3 \pm 0.3$ \\
\hline 28 & $15 \pm 3 *$ & $6.1 \pm 0.2$ & $5.0 \pm 0.3$ \\
\hline 30 & $15 \pm 3 *$ & $5.4 \pm 0.2$ & $3.5 \pm 0.2$ \\
\hline
\end{tabular}

Nitrite production was assessed, in the BALF of infected mice, during the course of chronic infection (Table 1). There was a sharp rise in the levels of nitrite in the lungs of infected mice on the third day post first infection. The levels decreased and again increased after the second and third infection and remained significantly high till $20^{\text {th }}$ post infection day in infected mice as compared to uninfected controls $(\mathrm{p}<0.05)$, followed by a steady decrease till $30^{\text {th }}$ day. Similar pattern was observed in malondialdehyde (MDA) production and lactate dehydrogenase (LDH) enzyme activity in the lung tissue of infected mice (Table 1).

Cytokine generation was also studied in the BALF of experimental animals during the course of chronic pneumonia. Two peaks were observed in the levels of pro-inflammatory cytokines, TNF $-\alpha$ and IL $-1 \beta$, after the first and the third infection with $K$. pneumoniae B5055. The levels for both the cytokines were statistically significant when compared to the uninfected controls shown as day $0(\mathrm{p}<0.01)$. With subsequent decrease in the lung bacterial load, there was also a corresponding decrease in the production of TNF- $\alpha$ and IL-1 $\beta$ in the lungs of infected mice (Fig. 3) There was a slow and gradual increase in the levels of anti-inflammatory cytokine IL-10 in the lungs of infected mice with maximum cytokine generation on day $28(\mathrm{p}<0.05)$. Thereafter, the levels of IL-10 declined.

\section{Discussion}

The severity of a lung infection is primarily determined by the virulence of the infecting strain. In the present study, $K$. pneumoniae B5055 strain was employed to induce chronic pneumonia in the experimental mice. This strain belongs to serotype 01:K2 which is the most commonly isolated serogroup from human clinical situations [12]. Selection of mouse for the model, coupled with the choice of frequently isolated strain from clinical situations, makes it more relevant to be able to extrapolate the results of the present study in relation to patients suffering from pneumonia caused by this organism. Limited studies are available where animal models have been used to describe chronic pneumonia by $K$. 
pneumoniae. Initially, Berendt et al. [4] described bronchopneumonia in rats, by intranasal inoculation of bacteria, but they eventually abandoned their model due to high mortality in the early phase of infection. The authors emphasized economical, practical and statistical advantages of using a rodent model. Domenico et al. [5] produced chronic lobar pneumonia model by intratracheal inoculation of bacteria in rats but again encountered the problem of an increase in lung bacterial counts coupled with the death of animals. These workers highlighted the importance of virulence of pathogenic strain used to induce lung infection in experimental animals. They demonstrated that, employing appropriate $K$. pneumoniae strain has a strong bearing on the nature and extent of the disease produced. Variants within a single population of same strain show marked difference in pathogenicity which is mainly attributed to CPS production [13]. In the present study, chronic pneumonia was established in normal BALB/c mice with $K$. pneumoniae B5055, which is a highly virulent encapsulated strain.

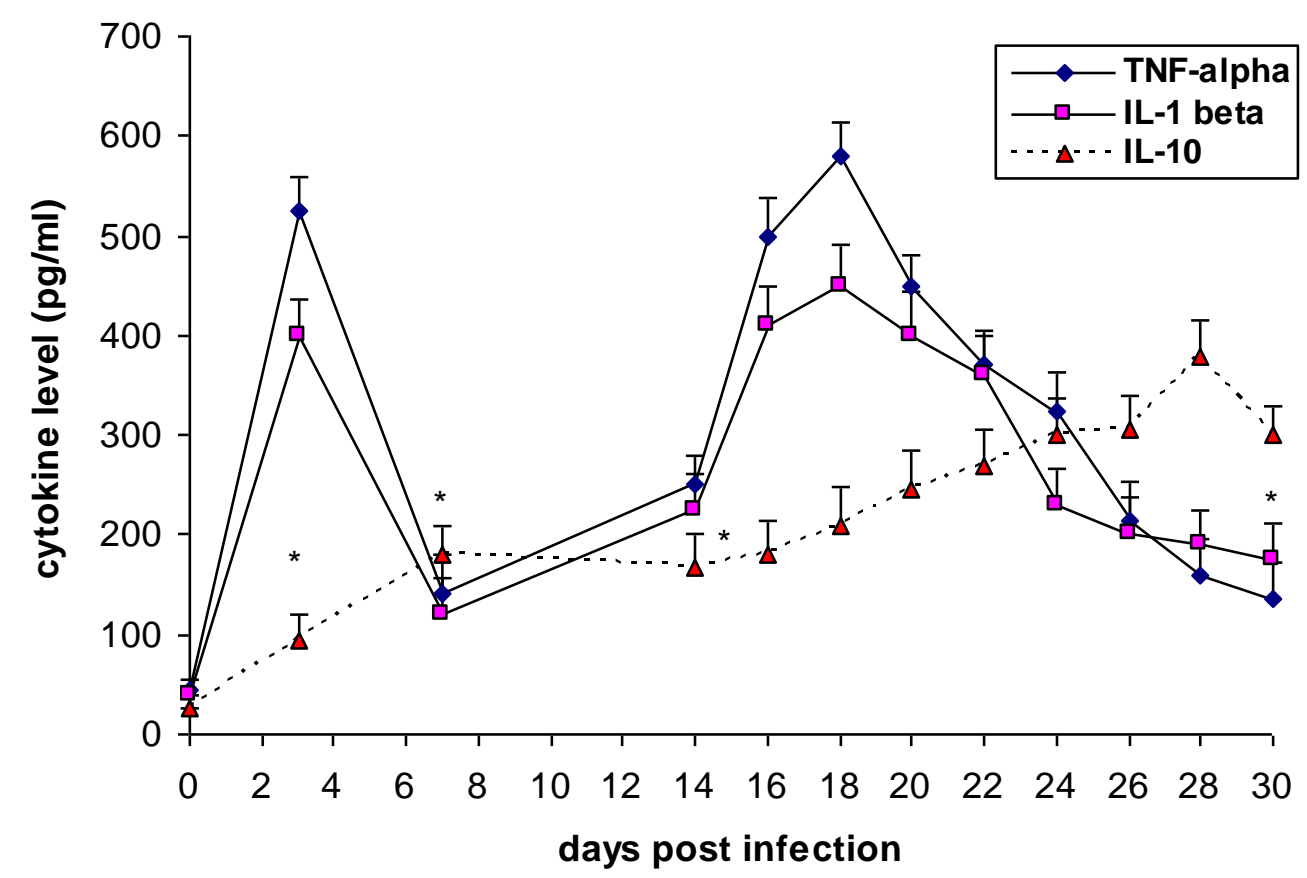

Figure 3: Levels of TNF- $\alpha$, IL-1 $\beta$ and IL-10 in the BALF of mice with experimentally induced chronic pneumonia employing $K$. pneumoniae. Error bars indicate the standard errors of mean. * denotes that the levels of cytokines were not statistically significant $(\mathrm{p}>0.05$ ) when compared to the uninfected controls (day 0$)$. On the other days, statistically significant difference $(\mathrm{p}<0.05)$ was observed when cytokine levels were compared to the control values.

Chronic pulmonary infection in mice by $K$. pneumoniae has so far been reported only by Iizawa et al. [7]. These workers observed a marked variation in susceptibility of a mouse strain to an experimental respiratory tract infection, besides high mortality towards the later part of observation period. In all these reports, experimental animals were exposed to only one infection dose of $K$. pneumoniae.
However, in the present study, a single intranasal exposure to the $K$. pneumoniae B5055 strain resulted in only acute pneumonia with signs of resolution after a week $[14,15]$. In order to achieve the chronic stage of infection, it is imperative that the bacterial count does not fall below a particular limit or get completely eliminated from the host thereby mitigating the need for repeated inoculation. Hence, to 
successfully establish chronic changes in the lungs of mice, three infection doses of $10^{4}$ $\mathrm{CFU} / \mathrm{ml}$ each were given intranasaly, at weekly intervals. The method of repeated exposures to a pathogen has also been successfully employed to establish chronic mucosal infections in mice including reports from our laboratory $[16,17$, 18].

Domenico et al. [5] observed the formation of chronic abscess, surrounded by a wall of collagen fibres, on $9^{\text {th }}$ day of infection. On the other hand, Iizawa et al. [7] reported that marked hyperplasia of lymphoid tissue was observed around the bronchi at 3 weeks postinfection time. However, no fibrosis was reported in their model. In the present study, the course of chronic pneumonia exhibited two peaks in the lung bacterial counts followed by a decline. Pathological findings in the infected lungs revealed extensive chronic inflammation on the $18^{\text {th }}$ post infection day. Chronic abscess formation with fibroblastic proliferation around the bronchioles and alveolar destruction at certain places was noted. Maximum tissue destruction was also demonstrable, through high generation of MDA and $\mathrm{LDH}$, in the lungs of infected animals. However, high nitric oxide production preceded a decrease in the lung bacterial load. This showed that nitric oxide seemed to play an antibacterial role in containing the chronic infection in a similar way as it does in acute pneumonia [9]. The characterization of the inflammatory response manifested in the form of pathological changes can be further studied in detail by employing specific cell markers.

In the present study, the inflammatory response generated during chronic pneumonia induced in mice by $K$. pneumoniae B5055 was assessed through the generation of proinflammatory (TNF- $\alpha$ and IL-1 $\beta$ ) and antiinflammatory (IL-10) cytokines. Two peaks of TNF- $\alpha$ and IL-1 $\beta$ were observed which could be attributed to the presence of high number of bacteria in the lungs of infected animals at those time periods. These elevated levels of the cytokines were succeeded by a fall in the lung bacterial load thereby suggesting a protective role played by the pro inflammatory cytokines.
This is the first study to describe the course of cytokine generation during the inflammatory process of $K$. pneumoniae induced chronic pneumonia. The beneficial role of TNF- $\alpha$ and IL-1 $\beta$ production during $K$. pneumoniae induced acute pneumonia is well known $[8,19$, 20]. To what extent these cytokines are important for the host defence during the course of chronic inflammatory response, needs further consideration. The kinetics of anti-inflammatory cytokine, IL-10, produced in the BALF in the present study showed that there was a gradual increase in the cytokine generation after the $3^{\text {rd }}$ infection. This increase in the production of IL10 coincided with a corresponding decline in TNF- $\alpha$ and IL- $1 \beta$ concentrations and also a subsequent decrease in the severity of infection. Thus, IL-10 appears to play a protective role in controlling the chronic infection by down regulating the inflammatory process. This anti inflammatory cytokine has also been shown to play an important role in ameliorating excessive inflammation during experimental chronic pneumonia induced by $P$. aeruginosa [21].

The present study brings out that chronic pneumonia can be successfully established in normal mice provided the bacteria are not cleared from the lungs. This can be achieved by repeated exposure of the host to the pathogen. Also, no mortality was observed till the end of the observation period which overcomes the limitations of earlier models and thus provides consistent results. The mouse model of chronic pneumonia described in this study, thus presents an ideal situation to obtain a deeper insight into the pathogenesis of $K$. pneumoniae and the interplay between various host and pathogen mechanisms.

\section{References}

1. Angeles-Garav, U., Chavez, Y.V., Flores, A.V.E., Martinez, J.C. and Guerrero, M.E.L. 2005. Nosocomial infections in a high speciality hospital. Factors associated to mortality in infected patient. Rev. Med. Inst. Mex. Seguro. Soc. 43: 381-391. 
2. Andriesse, G.L. and Verhoef, J. 2006. Nosocomial pneumonia: rationalizing the approach to empirical therapy. Treat. Respir. Med. 5: 11-30. DOI: 10.2165/00151829200605010-00002

3. Marrie, T.J. 2000. Community- acquired pneumonia in elderly. Clin. Infect. Dis. 31: 1066 -1078. DOI: 10.1086/318124

4. Berendt, R.F., Long, G.G., Abeles, F.B., Canonico, P.G., Elwell, M.R. and Powanda, M.C. 1977. Pathogenesis of respiratory Klebsiella pneumoniae infection in rats: bacteriological and histological findings and metabolic alterations. Infect. Immun. 15: 586593.

5. Domenico, P., Johanson, W.G.J. and Straus, D.C. 1982. Lobar pneumonia in rats produced by clinical isolates of Klebsiella pneumoniae. Infect. Immun. 37: 327-335.

6. Kamnasaran, D., O'Brien, P.C., FergusonSmith, M.A. and Cox, D.W. 2000. Comparative mapping of human chromosome 14q11.2-q13 genes with mouse homologous gene regions. Mamm. Genome. 11: 993-999. DOI: $10.1007 / \mathrm{s} 003350010183$

7. Iizawa, Y., Nischi, T., Kondo, M. and Imada, A. 1988. Experimental chronic pulmonary infection in mice caused by Klebsiella pneumoniae. Microbiol. Immunol. 32: 895-906. PMid:3062329

8. Laichalk, L.L., Kunkel, S.L., Strieter, R.M., Danforth, J., Baillie and Standiford, T.J. 1996. Tumor necrosis factor mediates lung antibacterial host defense in murine Klebsiella pneumoniae. Infect. Immun. 64 : 5211-5218. PMid:8945568

9. Tsai, W.C., Strieter, R.M., Zisman, D.A., Wilkowski, J.M., Bucknell, K.A., Chen, G. and Standiford, T.J. 1997. Nitric oxide is required for effective innate immunity against Klebsiella pneumoniae. Infect. Immun. 65: 1870-1875. PMid:9125574

10. Wills, E.D. 1965. Mechanism of lipid peroxide formation in animal tissues. J. Biochem. 99 : 667-676.

11. Vassault, A. 1983. Lactate dehydrognase, In Bergmeyer, H.U. and Grs. B.I. (eds.). Methods of enzymatic analysis vol.III. Verlag Chemic Gmb. H., D. Weinheim : 118-126.
12. Podschun, R. and Ullmann, U. 1998. Klebsiella spp. as nosocomial pathogens : epidemiology, taxonomy, typing methods, and pathogenicity factors. Clin. Microbiol. Rev. 11: 589-603. PMid:9767057

13. Pollack, M. 1976. Significance of circulating capsular antigen in Klebsiella infections. Infect. Immun. 13: 1543-1546.

14. Yadav, V., Sharma, S., Harjai, K., Mohan, H. and Chhibber, S. 2003. Induction and resolution of lobar pneumonia following intranasal instillation with Klebsiella pneumoniae in mice. Ind. J. Med. Res. 118: 47-52. PMid: 14748466

15. Sharma, S., Mohan, H., Sharma, S. and Chhibber, S. 2011. A comparative study of induction of pneumonia in mice with planktonic and biofilm cells of $K$. pneumoniae. Microbiol. Immunol. 55: 295-303. DOI: 10.1111/j.1348$\underline{0421.2011 .00317 . x}$

16. Yu, H., Hanes, M., Chrisp, C.E., Boucher, J.C. and Deretic, V. 1998. Microbial pathogenesis in cystic fibrosis: pulmonary clearance of mucoid Pseudomonas aeruginosa and inflammation in a mouse model of repeated respiratory challenge. Infect. Immun. 66: 280-288.

17. Gupta, R., Ganguly, N.K., Ahuja, V., Joshi, K. and Sharma, S. 1995. An ascending nonobstructive model for pyelonephritis in BALB/c mice. J. Med. Microbiol. 43: 33-36. DOI: 10.1099/00222615-43-1-33

18. Mittal, R., Kaur, A., Joshi, K., Nada, R., Chhibber, S., Harjai, K. and Sharma, S. 2009. Experimental non- obstructive chronic renal infection model with planktonic and biofilm cells of Pseudomonas aeruginosa. Am. J. Biomed. Sci. 1(2): 103-114. DOI: 10.5099/aj090200103

19. Yoshida, K., Matsumoto, T., Tateda, K., Uchida, K., Tsujimoto, S. and Yamaguchi, K. 2000. Role of bacterial capsule in local and systemic inflammatory responses of mice during pulmonary infection with Klebsiella pneumoniae. J. Med. Microbiol. 49: 1003-1010. PMid:11073154

20. Moore, T.A., Lau, H.Y., Cogen, A.L. and Standiford, T.J. 2005. Defective innate antibacterial host responses during murine Klebsiella pneumoniae bacteremia: tumor necrosis factor (TNF) receptor / deficiency 
versus therapy with anti-TNF-alpha. Clin. Infect. Dis. 41: 213s-217s. DOI: $10.1086 / 430126$

21. Chmiel, J.F., Konstan, M.W., Knesebeck, J.E., Hillard, J.B., Bonfield, T.L., Dawson, D.V. and Berger, M. 1999. IL-10 attenuates excessive inflammation in chronic Pseudomonas infection in mice. Am. J. Respir. Crit. Care Med. 160: 2040-2047. PMid:10588626 